
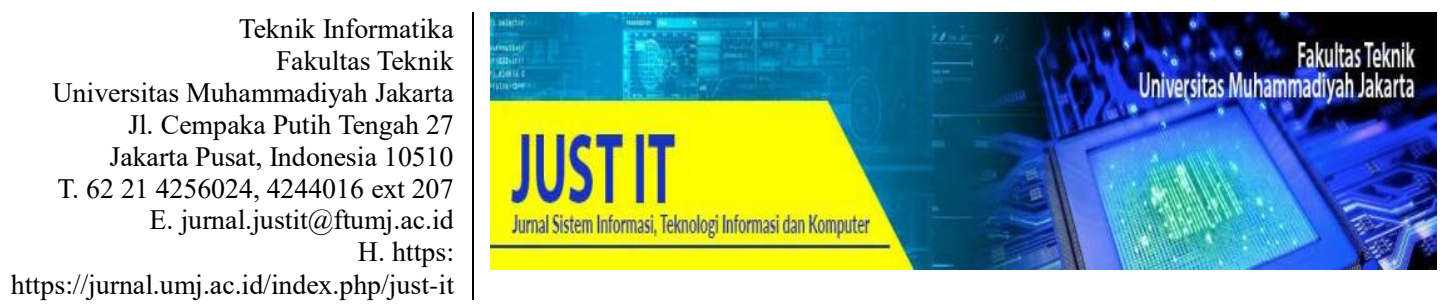

\title{
Pemodelan dan Simulasi Produksi untuk Mendukung Strategi Bisnis PT Majimak
}

\author{
Hikmah Rossyta V. ${ }^{1}$, Rizki Puji Lestari ${ }^{2}$, Nur Diana Saputri ${ }^{3}$, Dwi Rolliawati ${ }^{4}$ \\ Program Studi Sistem Infrmasi, Fakultas Sains dan Teknologi, \\ Universitas Islam Negeri Sunan Ampel
}

rossytahikmah2@gmail.com¹, rizki.pujilestari15@gmail.com²,nurdianasaputrii@gmail.com³, dwi_roll@uinsby.ac.id ${ }^{4}$

\begin{abstract}
Abstrak
Industri kerajian kayu merupakan industri yang masih eksis dan digemari masyarakat, kerajinan kayu tidak hanya digunakan sebagai hiasan semata namun sekarang ini sudah merambah hingga penambahan fungsi sebagai peralatan sehari hari. Seperti pada PT Majimak yang membutuhkan suatu strategi bisnis agar dapat bersaing dengan perusahaan lokal maupun perusahaan asing. Untuk melakukan analisis dalam menentukan strategi bisnis salah satunya dapat menggunakan analisis SWOT. Dengan analisis SWOT akan didapatkan karakteristik dari kekuatan utama, kekuatan tambahan, faktor netral, kelemahan utama dan kelemahan tambahan berdasarkan analisa lingkungan internal dan eksternal yang dilakukan. Penelitian ini merupakan jenis penelitian deskriptif dengan menggunakan data kuantitatif yang didapat dari laporan penjualan pada PT.Majimak. Penelitian ini menghasilkan faktor internal dan eksternal PT Majimak pada kuadran analisis SWOT PT Majimak berada pada kuadran I yang artinya strategi yang diterapkan membawa pada situasi yang cukup baik, maka strategi yang digunakan adalah strategi agresif atau pengembangan. Sehingga dapat disimpulkan bahawa analisis SWOT dapat mendukung strategi turn around dengan mengubah strategi yang dilakukan sebelumnya untuk mendapat hasil yang maksimal.
\end{abstract}

Kata Kunci: Pemodelan dan simulasi, Supply Chain Management, Analisis SWOT

\begin{abstract}
The wooden handicraft industry is an industry that still exists and is popular with the community, wood crafts are not only used as decoration but now it has expanded to add functions as daily equipment. As in PT Majimak which requires a business strategy in order to compete with local and foreign companies. To conduct analysis in determining business strategies, one of them can use SWOT analysis. With the SWOT analysis will get the characteristics of the main strengths, additional strengths, neutral factors, major weaknesses and additional weaknesses based on internal and external environmental analysis conducted. This research is a type of descriptive research using quantitative data obtained from sales reports at PT.Majimak. This research resulted in internal and external factors of PT Majimak in the quadrant of PT Majimak's SWOT analysis which was in quadrant I which means that the strategy adopted brought about a pretty good situation, so the strategy used was an aggressive or development strategy. So it can be concluded that the SWOT analysis can support the turn around strategy by changing the strategy carried out previously to get maximum results.
\end{abstract}

Keywords: Modeling and simulation, Supply Chain Management, SWOT Analysis 


\section{PENDAHULUAN}

Industri kerajian kayu merupakan industri yang masih eksis dan digemari masyarakat. Kerajinan kayu tidak hanya digunakan sebagai hiasan namun sudah merambah hingga penambahan fungsi sebagai peralatan sehari hari. PT Majimak merupakan salah satu PT kerajinan kayu asal Jepara yang memproduksi berbagai peralatan sehari-hari seperti piring, mangkok, sendok, garpu dan lain sebagainya. Walaupun produksi yang dihasilkan cukup unik tidak dapat dipungkiri masih terdapat banyak pesaing dalam industri kerajinan kayu. Pesaing tidak hanya berasal dari perusahaan lokal melainkan juga perusahaan asing. Untuk dapat bersaing dengan perusahaan lokal maupun perusahaan asing dibutuhkan strategi yang baik dan tepat sasaran.

Penentuan strategi dapat dilakukan dengan menggunakan salah satu metode analisis data yaitu analisis SWOT (strenght, weakness, Opportunity, Threat). Analisis SWOT menganalisis kekuatan, kelemahan, peluang dan ancaman dalam perusahaan yang kemudian disimpulkan untyuk menentukan strategi yang dapat digunakan. Hal penting yang perlu dilakukan analisis mendalam adalah proses produksi, proses pemasaran dan tingkat penjualan. Proses produksi merupakan salah satu faktor penentu keberhasilan perusahaan setelah faktor pemasaran. Dalam proses produksi diperlukan beberapa hal seperti modal, tenaga kerja dan teknologi yang merupakan faktor penting yang mempengaruhi dalam proses produksi. Proses produksi dapat dilakukan kontrol dengan membuat pemodelan dan simulasi aktivitas selama proses produksi (Wahyu, 2004). Pengontrolan proses produksi dapat meningkatkan pengelolaan manajemen produksi yang tepat dan dapat digunakan dalam penentuan strategi bisnis perusahaan yang lebih baik.

\section{TINJAUAN PUSTAKA}

\section{A. Analisis SWOT}

Analisis SWOT adalah suatu cara penilaian terhadap hasil identifikasi situasi, untuk menentukan kategori dari suatu kondisi yakni termasuk kekuatan (Strengths), kelemahan (Weaknesses), peluang (Opportunities) atau ancaman (Threats). Analisis SWOT termasuk bagian dalam proses perencanaan yang digunakan untuk melakukan penilaian mengenai kondisi saat ini dan gambaran masa depan yang mempengaruhi proses pencapaian tujuan dari institusi. Dengan analisa SWOT akan didapatkan karakteristik dari kekuatan utama, kekuatan tambahan, faktor netral, kelemahan utama dan kelemahan tambahan berdasarkan analisa lingkungan internal dan eksternal yang dilakukan (Istiqomah \& Andriyanto, 2018).

\section{Strategi Bisnis}

Menurut para ahli, perencanan strategi jangka panjang merupakan turunan dari misi/ usaha untuk mencari dasar keunggulan bersaing dari strategi generik (Suci, 2009) yakni:

a. Mengejar untuk mencapai biaya rendah (overall Cost Leadership) dalam industri. Dalam upaya pengendalian biaya perusahaan dilakukan efesiensi biaya yang dapat diperoleh dari memiliki karyawan yang berpengalaman, pengendalian biaya everhead, meminimalkan biaya penelitian dan pengembangan, service, wiraniaga, periklanan dan lain sebagainya.

b. Mengejar untuk menciptakan produk yang unik untuk pelanggan yang bervariasi atau differensiasi (differentiation). Differensiasi ini dapat dilakukan melalui dimensi citra rancangan atau merk, teknologi yang digunakan, karakteristik khusus, service pada pelanggan dan punya distribusi yang lebih baik. Keunggulan dalam menggunakan differensiasi adalah perolehan laba di atas rata-rata, kepekaan konsumen terhadap harga kurang, produk-produk differensiasi menciptakan tingginya hambatan yang masuk dan mudahnya menggantikan posisi terhadap produk pengganti

c. Mengejar untuk melayani permintaan khusus pada satu atau beberapa kelompok konsumen atau industri. Memfokuskan (focusting) pada biaya atau diferensiasi.

Strategi bisnis di atas dapat disebut dengan strategi generik yang telah dikembangkan oleh Porter (1980). 


\section{Supply Chain Logistic}

Supply chain adalah sekumpulan aktifitas (dalam bentuk entitas/fasilitas) yang terlibat dalam proses transformasi dan distribusi barang mulai dari bahan baku dasar dari alam sampai produk jadi pada konsumen yang apling akhir. (Anwar, 2013) Berdasarkan definisi diatas, maka didapatkan beberapa pemain utama supply chain yang merupakan perusahaan dengan kepentingan yang sama, yaitu :

\section{Supplies \\ 2. Manufactures \\ 3. Distribution \\ 4. Retail Outlet \\ 5. Customers}

Menurut Council of Logistic Management (CLM), logistic adalah bagian dari proses manajemen rantai pasokan (Supply Chain Management) yang meliputi perencanaan, perwujudan serta pengendalian efisiensi dan efektifitas aliran dan penyimpanan barang dan jasa dan informasi terkait antara titik konsumsi untuk memenuhi kebutuhan pelanggan. Logistik memiliki peran penting untuk memastikan bahwa suatu produk yang dihasilkan adalah tepat (right product) berada ditempat yang tepat, pada waktu yang tepat, dan dalam kondisi yang tepat dengan harga yang tepat untuk kepuasan pelanggan. Kegiatan-kegiatan dalam kinerja logistic meliputi pergudangan, packing, kegiatan pihak ketiga, transportasi inbound dan outbound, pendistribusian, inventory control, purchasing, planning lokasi dan pengelolaan maintenance produksi dan pelanggan satisfaction (Hayati, 2014).

\section{Pemodelan \& Simulasi Produksi}

Model adalah suatu analogi atau representasi sistem nyata yang dapat membantu mendeskripsikan sesuatu yang tidak dapat diamati secara langsung, sedangkan simulasi dapat diartikan sebagai suatu program atau software yang digunakan untuk menirukan perilaku sistem nyata (realitas) tertentu. Tujuan simulasi adalah untuk training atau pelatihan, behaviour atau studi perilaku sistem, serta game sebagai permainan dan hiburan (Mahessya, 2017).

\section{METODOLOGI PENELITIAN}

Alur penyelesaian penelitian dirangkum dalam flowchart metodologi penelitian berikut :

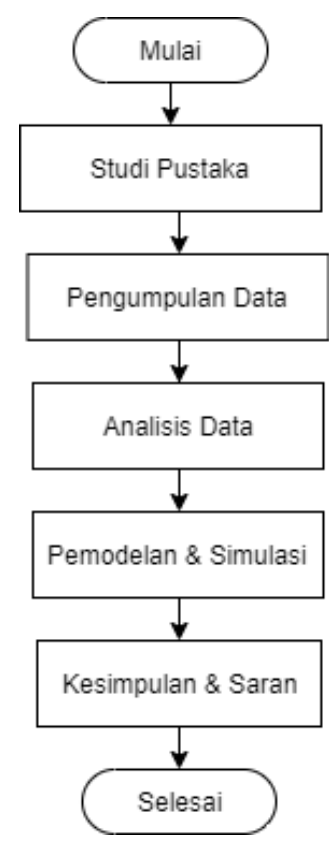

Gambar 1. Flowchart Metodologi Penelitian

\section{Jenis Penelitian}

Penelitian ini merupakan jenis penelitian Deskriptif. Yang dimaksud dengan penelitian deskriptif adalah melakukan penyelidikan keadaan, kondisi dan atau hal lain yang terkait dengan hasil yang dipaparkan dalam laporan penelitian (Arikunto, 2019) dengan menggunakan data kuantitatif yang di dapat dari laporan penjualan pada PT. Majimak.

\section{Metode Pengumpulan Data}

Metode pengumpulan data yang dilakukan dalam penelitian ini yaitu :

a. Observasi

Observasi dilakukan dengan cara mengamati, mengumpulkan, mempelajari dan mencatat langsung tentang sistem pembelian sampai pembuatan laporan. Dalam metode ini setiap data dicatat langsung, sehingga dapat menghasilkan informasi yang tepat dan akurat

b. Wawancara 
Wawancara dilakukan dengan mengajukan beberapa pertanyaan kepada dilakukan kepada pemilik PT. Majimak

\section{Metode Analisis Data}

Metode yang digunakan dalam menentukan strategi dalam penelitian ini adalah analisis swot, dengan meneliti kekuatan, kelemahan, peluang dan ancaman pada perusahaan. Terdapat 4 bagian dalam analisis SWOT yaitu strengths (kekuatan), weakness (kelemahan), opportunities (kesempatan) dan threats (ancaman).

Pada bagian strengths (kekuatan) dan weakness (kelemahan) biasanya dipengaruhi faktor yang berasal dari internal perusahaan seperti: lokasi perusahaan, reputasi bisnis dan lain sebagainya. Sedangkan opportunities (kesempatan) dan threats (ancaman) biasanya berasal dari external perusahaan seperti: pemasok kompetitor, harga pasar dan lain sebagainya.

\section{HASIL DAN PEMBAHASAN}

\section{Pemodelan dan Simulasi Produksi}

Permodelan dan simulasi produksi dilakukan untuk memodelkan dan mensimulasikan atau menggambarkan aktivitas produksi yang disesuaikan dengan data real suatu produksi. Berikut adalah flowchart produksi pada PT. Majimak:

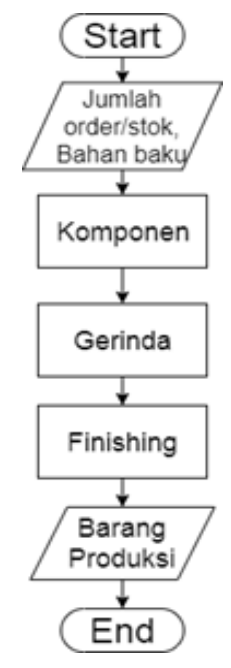

Gambar 2. Flowchart Produksi pihak yang terlibat. Wawancara akan

Beberapa proses yang ada dalam proses produksi diantaranya :

a. Komponen

Komponen adalah aktivitas mulai dari membentuk kayu sesuai pola, dan memberi lubang.

b. Gerinda

Memperhalus hasil komponen dengan menggunakan alat gerinda.

c. Finishing

Menghaluskan kayu menggunakan kayu dan memberi minyak dengan alat gerinda. Pada PT. Majimak terdapat 20 jenis bentuk kerajinan kayu namun memiliki proses dan lama produksi yang hampir sama. Berikut adalah data produksi pada PT. Majimak :

TABEL 1

WAKTU PROSES PRODUKSI

\begin{tabular}{|c|c|c|}
\hline Proses & Min/ menit & $\begin{array}{c}\text { Max/ } \\
\text { menit }\end{array}$ \\
\hline Komponen & 6 & 9 \\
\hline Gerinda & 6 & 9 \\
\hline Finishing & 9 & 10 \\
\hline
\end{tabular}

TABEL 2

DATA PRODUKSI

\begin{tabular}{|l|c|}
\hline Rata-Rata Penjualan & 2 Kali / bulan \\
\hline $\begin{array}{l}\text { Rata-Rata Jumlah Produk/ } \\
\text { Order }\end{array}$ & 200 / Jenis \\
\hline
\end{tabular}

Jadi dapat disimpulkan setiap bulan akan memproduksi 8000 produk, jika libur 4 kali/bulan maka perhari akan memproduksi sebanyak 308 produk.

\section{Implementasi Pada Anylogic}

Data produksi dalam implementasi pada anylogic:
1. Source
Berisi poin awal dalam sebual model.
Dalam studi kasus produksi berisi jumlah produk yang diproduksi. Pada MT majimah dalam 1 hari mampu memproduksi 308 produk.
2. Service 
Dalam proses produksi PT. Majimak terdapat 3 service yang terangkum dalam tabel berikut:

TABEL 3 DISTRIBUSI ELEMEN PROSES

\begin{tabular}{|c|c|c|}
\hline Proses & Elemen Proses & $\begin{array}{c}\text { Jenis } \\
\text { Distribusi }\end{array}$ \\
\hline 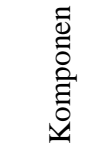 & $\begin{array}{l}\text { Antrian produk } \\
\text { dalam proses } \\
\text { komponen }\end{array}$ & $\begin{array}{c}\text { uniform }_{-} \\
\operatorname{discr}(6,10)\end{array}$ \\
\hline 莺 & $\begin{array}{c}\text { Antrian produk } \\
\text { dalam proses } \\
\text { Gerinda }\end{array}$ & $\begin{array}{c}\text { uniform }_{-} \\
\text {discr }(6,10)\end{array}$ \\
\hline 点 & $\begin{array}{l}\text { Antrian produk } \\
\text { dalam proses } \\
\text { Finishing }\end{array}$ & $\begin{array}{c}\text { uniform } \\
\text { discr }(9,12)\end{array}$ \\
\hline
\end{tabular}

Dibawah ini adalah penjelasan dari tabel 3 :

\section{a. Komponen}

Pada service komponen terdapat 2 resource pool yaitu pekerja dan kayu. Pekerja pada proses komponen terdiri dari 3 orang, sedangkan kayu yang dibutuhkan sebanyak 13 papan dengan menghasilkan rata-rata 13 produk/papan. Dengan max capacity 200 dan delay time uniform_discr $(6,10)$ karena dalam 1 hari maksimal dapat memproduksi 200 produk dengan proses komponen min 6 menit dan maksimal 10 menit.

b. Gerinda

Membentuk hasil komponen agar bentuk lebih bagus. Proses gerinda membutuhkan resource 3 pekerja dan 3 alat gerinda. Maksimum capacity 200 dan delay time uniform_discr $(6,10)$.

c. Finishing

Menghaluskan kayu menggunakan tangan manual dan memberi minyak dengan alat gerinda. Resource yang dibutuhkan adalah 3 pekerja, 3 alat gerinda dan 3 minyak. Maksimum capacity 200 dengan delay time uniform_discr $(9,12)$.

3. Sink

Poin akhir pada model. Menandakan berakhirnya proses.
Berikut adalah simulasi produksi PT. Majimak pada anylogic :

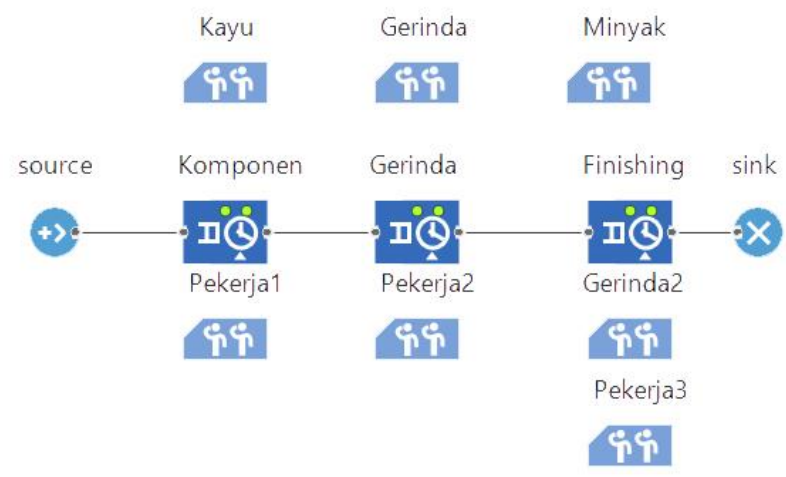

Gambar 3. Proses Simulasi pada AnyLogic

Untuk mengetahui jumlah produk yang sedang diproses dan output yang telah keluar dari proses dapat ditambahakan chart dengan menggunakan source.count() untuk menghitung produk yang masuk untuk diproses dan sink.count() untuk menghitung produk yang telah selesai diproses. Penerapan dalam anylogyc dapat dilihat pada gambar dibawah ini:

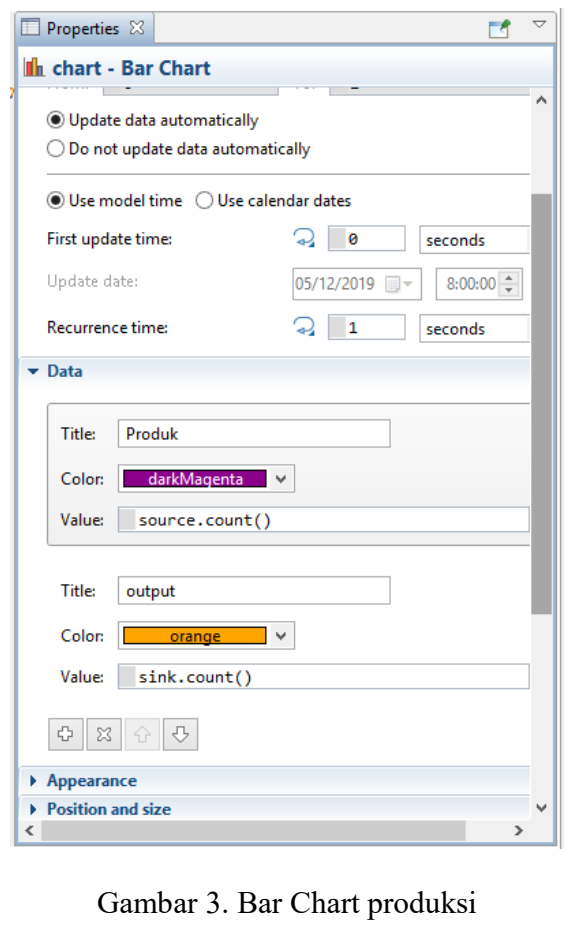

Berikut adalah hasil simulasi dan permodelan PT. Majimak pada anylogyc : 


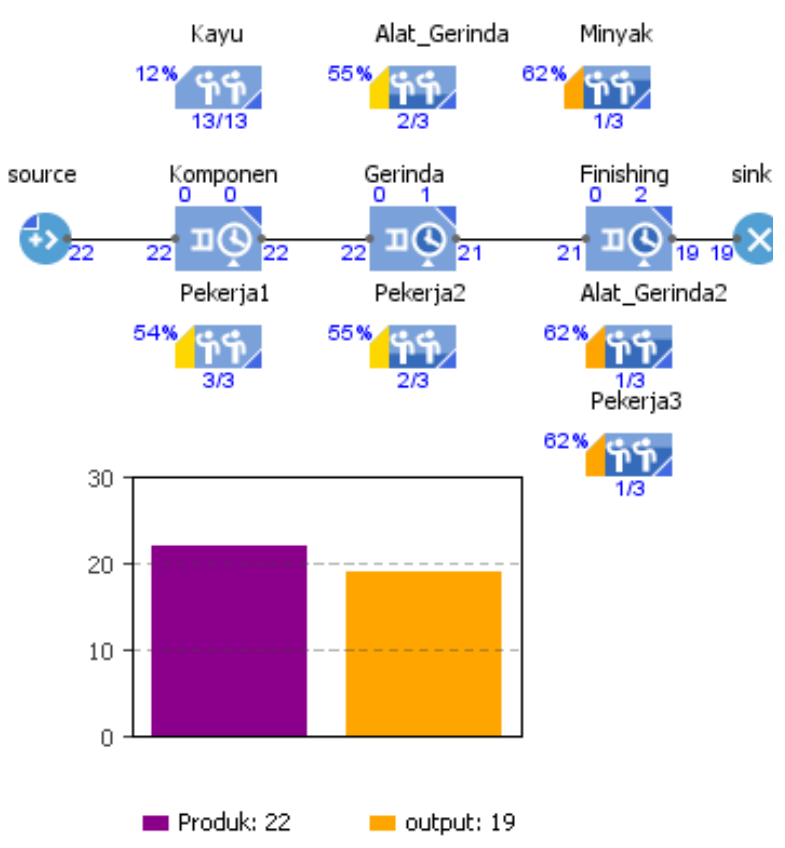

Dapat disimpulkan dari hasil pemodelan dan simulasi PT Majimak dapat melakukan proses produksi dengan jangka waktu yang cukup singkat. Namun dari laporan penjualan PT Majimak dalam kurun waktu 1 tahun hanya mempunyai 7 nama pembeli yang sama. Hal ini dapat menjadi penghambat dalam pengembangan bisnis. Untuk itu dilakukan analisis SWOT untuk menentuka strategi dalam mengembangkan bisnis PT. Majimak

\section{Tahap Analisis}

Analisis faktor internal (kekuatan dan kelemahan) yang dimasukkan dalam matriks faktor IFAS (Internal Strategic Factors Analisys Summary) yang disesuaikan berdasarkan kondisi perusahaan dengan menghitung bobot dan rating.

Gambar 4. Simulasi Produksi pada AnyLogic

TABEL 4

TABEL MATRIKS IFAS

\begin{tabular}{|c|c|c|c|c|}
\hline $\begin{array}{c}\text { Komponen } \\
\text { SWOT }\end{array}$ & Faktor Eksternal & Bobot & Rating (1-4) & Nilai \\
\hline \multirow{7}{*}{ 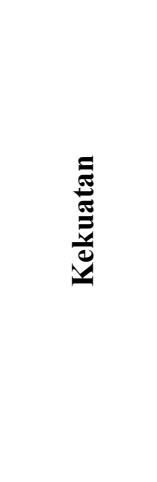 } & 1. Mampu memproduksi dalam jumlah besar & 0,09 & 4 & 0,36 \\
\hline & 2. Mempunyai cukup modal & 0,12 & 3 & 0,36 \\
\hline & 3. Mempunyai banyak tenaga kerja & 0,06 & 3 & 0,18 \\
\hline & 4. Memproduksi barang yang beragam & 0,10 & 4 & 0,40 \\
\hline & 5. Mempunyai peralatan yang cukup lengkap & 0,08 & 4 & 0,32 \\
\hline & 6. Stock barang yang selalu ada & 0,11 & 3 & 0,33 \\
\hline & Total Kekuatan & 0,56 & 21 & 1,95 \\
\hline \multirow{6}{*}{ 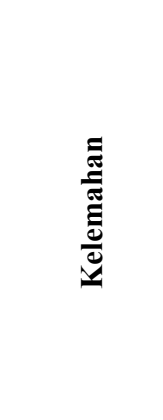 } & 1. Penjualan hanya dilakukan freind to friend & 0,12 & 4 & 0,48 \\
\hline & $\begin{array}{l}\text { 2. Melakukan perubahan harga tanpa mempertimbangan } \\
\text { biaya produksi }\end{array}$ & 0,10 & 3 & 0,30 \\
\hline & 3. Tidak melakukan aktivitas pemasaran online & 0,10 & 4 & 0,40 \\
\hline & 4. Lokasi produksi kurang strategis & 0,06 & 3 & 0,36 \\
\hline & 5. Molornya waktu produksi & 0,06 & 3 & 0,18 \\
\hline & Total Kelemahan & 0,44 & 20 & 1,72 \\
\hline \multicolumn{2}{|r|}{ Total } & 1 & 28 & 2,85 \\
\hline
\end{tabular}


Dilihat Dari hasil matriks IFAS pada tabel 1.1 dapat diambil kesimpulan bahwa memproduksi barang yang beragam merupakan kekuatan utama yang dimiliki dengan nilai sebesar 0,40 sedangkan kelemahan utamanya adalah penjualan hanya dilakukan friend to friend dengan nilai 0,48 . Hal ini menunjukkan bahwa kelemahan yang dimiliki lebih besar dibanding dengan kekuatan yang dimiliki PT
Majimak.

1. Analisis Faktor External (Peluang dan Ancaman) yang dimasukkan dalam matriks faktor EFAS (External Strategyc Factors Analisys Summary) yang disesuaikan berdasarkan kondisi perusahaan dengan menghitung bobot dan rating.

TABEL 5

TABEL MATRIKS SWOT

\begin{tabular}{|c|c|c|c|c|}
\hline $\begin{array}{l}\text { Komponen } \\
\text { SWOT }\end{array}$ & Faktor Eksternal & Bobot & Rating (1-4) & Nilai \\
\hline \multirow{6}{*}{ 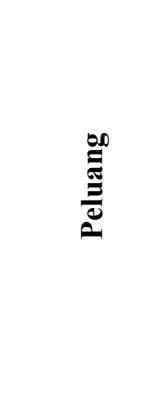 } & 6. Menciptakan berbagai produk baru & 0,12 & 3 & 0,36 \\
\hline & 7. Dapat mengikuti trend produk kerajinan kayu & 0,10 & 3 & 0,30 \\
\hline & $\begin{array}{l}\text { 8. Lingkungan yang mendukung kemudahan mendapatkan } \\
\text { resource }\end{array}$ & 0,11 & 2 & 0,22 \\
\hline & 9. Peminat kerjianan kayu yang terus meningkat & 0,08 & 3 & 0,24 \\
\hline & $\begin{array}{l}\text { 10. Perkembangan teknologi dapat memudahkan dalam } \\
\text { melakukan proses marketing }\end{array}$ & 0,09 & 3 & 0,27 \\
\hline & Total Peluang & 0,5 & 14 & 1,39 \\
\hline \multirow{6}{*}{ 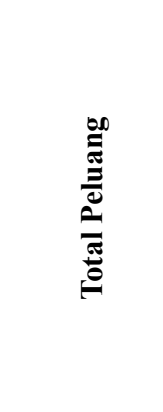 } & 1. Ketatnya persaingan dalam industri kerajinan kayu & 0,13 & 4 & 0,52 \\
\hline & 2. Adanya ancaman dari pesaing dengan ide unik & 0,11 & 3 & 0,33 \\
\hline & 3. Tingginya harga tenaga kerja & 0,10 & 2 & 0,20 \\
\hline & 4. Turunnya permintaan & 0,09 & 3 & 0,27 \\
\hline & 5. Harga bahan baku yang cukup tinggi & 0,07 & 2 & 0,14 \\
\hline & Total Ancaman & 0,5 & 14 & 1,46 \\
\hline \multicolumn{2}{|r|}{ Total } & 1 & 28 & 2,85 \\
\hline
\end{tabular}

Peluang utama dari hasil matrix EFAS adalah Menciptakan produk-produk baru dengan nilai sebesar 0,36 sedangkan ancaman utamanya adalah persaingan yang ketat dalam industri kerajinan kayu dengan nilai 0,52. Dilihat dari hasil besarnya peluang dan ancaman dapat diartikan bahwa PT Majimak kurang dapat memanfaatkan peluang untuk mengurangi ancaman.

\section{Tahap Pencocokkan}

Tahap pencocokan dilakukan untuk menemukan strategi yang dapat dirumuskan setelah dilakukannya analisis dan identifikasi faktorfaktor internal maupun eksternal perusahaan. Model yang akan digunakan adalah dengan menggunakan matriks SWOT (Strength Weakness Opportunities Threat. 
TABEL 6

MATRIKS SWOT

\begin{tabular}{|c|c|c|}
\hline $\begin{array}{l}\text { Faktor } \\
\text { Internal }\end{array}$ & $\begin{array}{l}\text { Strenght (W) } \\
\text { 1. Mampu memproduksi dalam } \\
\text { jumlah besar } \\
\text { 2. Mempunyai cukup modal } \\
\text { 3. Mempunyai banyak tenaga kerja } \\
\text { 4. Memproduksi barang yang } \\
\text { beragam } \\
\text { 5. Mempunyai peralatan yang cukup } \\
\text { lengkap } \\
\text { 6. Stock barang yang selalu ada }\end{array}$ & $\begin{array}{l}\text { Weakness }(\mathbf{W}) \\
\text { 1. Penjualan hanya dilakukan freind to } \\
\text { friend } \\
\text { 2. Melakukan perubahan harga tanpa } \\
\text { mempertimbangan biaya produksi } \\
\text { 3. Tidak melakukan aktivitas pemasaran } \\
\text { online } \\
\text { 4. Lokasi produksi kurang strategis } \\
\text { 5. Molornya waktu produksi }\end{array}$ \\
\hline $\begin{array}{l}\text { Opportunities (O) } \\
\text { 1. Menciptakan berbagai produk } \\
\text { baru } \\
\text { 2. Dapat mengikuti trend produk } \\
\text { kerajinan kayu } \\
\text { 3. Lingkungan yang mendukung } \\
\text { kemudahan mendapatkan } \\
\text { resource } \\
\text { 4. Peminat kerjianan kayu yang } \\
\text { terus meningkat } \\
\text { 5. Perkembangan teknologi dapat } \\
\text { memudahkan dalam melakukan } \\
\text { proses marketing. }\end{array}$ & $\begin{array}{l}\text { Strategi S-O } \\
\text { 1. Memanfaatkan modal untuk } \\
\text { mengikuti trend produk(S2, O2) } \\
\text { 2. Melakukan stok barang produk } \\
\text { baru (S6, O1) } \\
\text { 3. Mengoptimlakan penjualan stok } \\
\text { dengan memanfaatkan teknologi } \\
\text { dalam proses marketing (S6, O5) }\end{array}$ & $\begin{array}{l}\text { Strategi W-O } \\
\text { 1. Mengembangkan cara penjualan } \\
\text { dengan membuka toko online sebagai } \\
\text { bentuk pemanfaatan teknlogi (W3, } \\
\text { O5) } \\
\text { 2. Cara penjualan friend to friend harus } \\
\text { dirubah mengingat peminat kerjinan } \\
\text { kayu semakin meningkat (W1,O4) }\end{array}$ \\
\hline $\begin{array}{l}\text { Threat }(\mathbf{T}) \\
\text { 1. Ketatnya persaingan dalam } \\
\text { industri kerajinan kayu } \\
\text { 2. Adanya ancaman dari pesaing } \\
\text { dengan ide unik } \\
\text { 3. Tingginya harga tenaga kerja } \\
\text { 4. Turunnya permintaan } \\
\text { 5. Harga bahan baku yang cukup } \\
\text { tinggi }\end{array}$ & 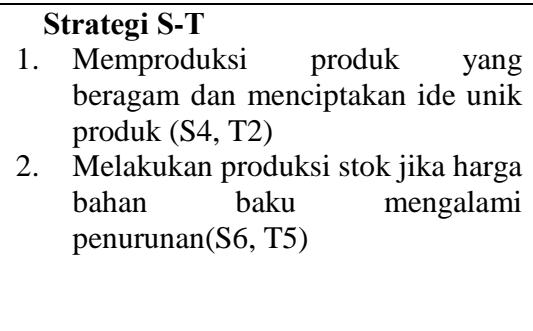 & $\begin{array}{l}\text { Strategi W-T } \\
\text { 1. Melakukan metode cross selling } \\
\text { untuk menghadapi persaingan } \\
\text { industri (W2, T1) } \\
\text { 2. Molornya produksi harus diatasi } \\
\text { dengan melakukan manajemen waktu } \\
\text { mengingat tingginya harga tenaga } \\
\text { kerja (W5, T3) }\end{array}$ \\
\hline
\end{tabular}

\section{Kuadran Analisis Swot}

Berdasarkan hasil analisis internal dan eksternal maka diperoleh :

1. Analisis Faktor Internal

$$
\begin{array}{ll}
\text { Strenght }(\mathrm{S}) & =1,95 \\
\text { Weakness }(\mathrm{W}) & =1,72 \\
\text { S-W } & =0,23
\end{array}
$$

2. Analisis Faktor Eksternal

$$
\begin{array}{ll}
\text { Opportunities }(\mathrm{O}) & =1,39 \\
\text { Threat }(\mathrm{T}) & =1,46 \\
\mathrm{O}-\mathrm{T} & =0,07
\end{array}
$$

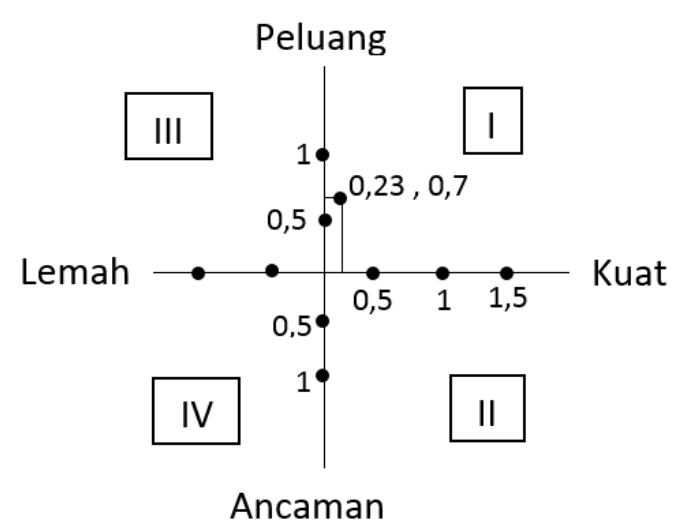

Gambar 5. Kuadran Analisis SWOT

Setelah diidentifikasi faktor internal dan 
eksternal PT Majimak pada kuadran analisis SWOT PT Majimak berada pada kuadran I yang artinya strategi yang diterapkan membawa pada situasi yang cukup baik, maka strategi yang digunakan adalah strategi agresif atau pengembangan. Hasil yang diperoleh faktor eksternal lebih besar dibandingkan faktor internal.

\section{KESIMPULAN}

Strategi yang diterapkan pada home industry PT. Majimak selama ini masih belum efektif dimana dapat diketahui setelah dilakukannya analisis SWOT faktor internal masih lebih kecil dari faktor eksternal perusahaan sehingga perusahaan berada pada kuadran I yaitu mendukung strategi turn around dengan mengubah strategi yang dilakukan sebelumnya untuk mendapat hasil yang maksimal.

\section{DAFTAR PUSTAKA}

Andriyanto, I. (2019). Analisis SWAnwar, S. N. (2013). Manajemen Rantai Pasokan (Supply Chain Management): Konsep dan Hakikat.

Arikunto, S. (2019). Prosedur penelitian suatu pendekatan praktik.

Hayati, E. N. (2014). Supply Chain Management (Scm) Dan Logistic Management. Jurnal Ilmiah Dinamika Teknik, 8(1).

Istiqomah, I., \& Andriyanto, I. (2018). Analisis SWOT dalam Pengembangan Bisnis (Studi pada Sentra Jenang di Desa Kaliputu Kudus). BISNIS: Jurnal Bisnis Dan Manajemen Islam, 5(2), 363-382.

Mahessya, R. A. (2017). Pemodelan Dan Simulasi Sistem Antrian Pelayanan Pelanggan Menggunakan Metode Monte Carlo Pada Pt Pos Indonesia (Persero) Padang. Jurnal Ilmu Komputer, 6(1), 15-
24.

Suci, R. P. (2009). Peningkatan kinerja melalui orientasi kewirausahaan, kemampuan manajemen, dan strategi bisnis (Studi pada Industri Kecil Menengah Bordir di Jawa Timur). Jurnal Manajemen Dan Kewirausahaan, 11(1), 46-58.

OT dalam Pengembangan Bisnis ( Studi pada Sentra Jenang di Desa Wisata Kaliputu Kudus ), 5(2), 363-382.

Designing And Managing The Supply Chain", Mc Graw - Hill Companies Inc, United States of America.

Machfoedz, Mahmud. 2005. Pengantar Pemasaran Modern. Yogyakarta: Unit Penerbit dan Percetakan Akademi Manajemen Perusahaan YKPN.

Nizar Sapta Nuary. (2016). Strategi Pemasaran Dengan Pendekatan Analisis Swot Pada Pt. Super Sukses Motor Banjarmasin Nizar.

Noor, S. (2014). Penerapan Analisis Swot Dalam Menentukan Strategi Pemasaran Daihatsu Luxio Di Malang (Studi Kasus Pada PT. Astra International Tbk. - Daihatsu Malang), (2).

Ramadhan, A., \& Sofiyah, F. R. (2013). Analisis SWOT sebagai landasan dalam menentukan strategi pemasaran ( studi McDonald 's Ring Road ) This research aims to identify and analyze the ma rketing strategy of McDoanald ' s Ring Road by using the SWOT analysis consisting of Strength , Weakness .

Susilawati, Iis Mei \& Harun, Muhammad. 2017. Analisis SWOT Sebagai Dasar Strategi Branding pada Madrasah Ibtidaiyah Alhidayah, Cireunde Ciputat.

Taringan, Zeplin Jiwa Husada. 2005. Perancangan Penjualan dan Perencanaan Produksi yang Terintegrasi dengan Menerapkan Teknologi Enterprise Resource Planning. Jurnal Tenik Industri Vol.7 No.2 